\title{
The internet era: the
} development of electronic commerce in China - and a need for global dispute resolution processes

\author{
by Anthony Connerty
}

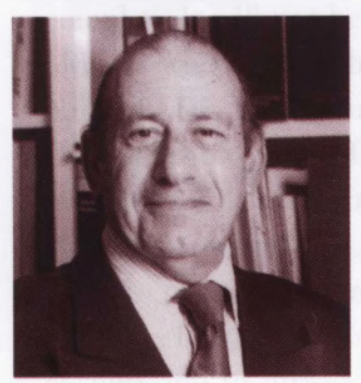

Anthony Connert
This article examines the development of electronic commerce worldwide, particularly in China, as well as the problems of dispute resolution in the context of electronic commerce.
$\mathrm{N}$ o-one can predict with certainty where the internet will take us. One area where it has particular impact is commerce. Cross-border trading can take place on the internet virtually without regard to national boundaries. The problems thus raised for politicians, lawyers and legislators are immense.

Broadly speaking there are two types of business on the internet: that between business and the consumer and that between business and business. If the increase in consumer business on the internet in Britain follows the trend in America, then the rate of growth will be staggering. The estimated business-to-consumer trading in America presently put at $\$ 8$ billion is reckoned to increase to $\$ 108$ billion over the next five years.

The business-to-consumer market (B2C) is small beer compared to the business-to-business trading (B2B). The American forecasts for inter-company trading put the present figure at $\$ 43$ billion increasing to $\$ 1.3$ trillion in 2003. One factor which might affect those forecasts is the type of company which is presently trading on the internet. Well-known are the new internet companies such as Amazon and Yahoo! More important may be established firms which have not yet taken full advantage of the benefits the internet can offer.

\section{THE DEVELOPMENT OF ELECTRONIC COMMERCE IN CHINA}

In the ten years to 1997 , the telecommunications sector in China grew at an extraordinary rate. In 1996, for example, China added over 12 million lines, an increase equivalent to the entire telephone network of Canada. The use of pagers in China was amongst the world's largest, with an estimated 40 million users. By 1997 some seven million mobile telephones were in use.

In March 1999, China Telecom, China's largest internet service provider, lowered its charges for both telephone and internet services. It was estimated that this would lead to a considerable growth in use of the internet. The number of internet users at the end of 1998 was put at two million. That was estimated to double or triple in 1999.

The Chinese government has invested heavily in information technology: US $\$ 50$ billion has been invested in telecoms and data-processing hardware. Since 1993, a fibre-optic grid has been laid across the country. Eight high-capacity lines run north-south, with eight running east-west, connecting China's principal cities. This has enabled new telephone lines to be installed at an extraordinary rate. There are 125 million lines, with something in excess of two million more being laid each 
month. The use of mobile phones increases even more quickly: from five million mobile phone users in 1995 to more than 57 million today. In 1995 there were less than 50,000 internet-users in China. The latest statistics from the Chinese government are that there were 2.1 million users at the beginning of 1999, 8.9 million at the end of that year and that by the end of the year 2000 the figure is expected to be 20 million.

There are now 48,000 registered domain names in China and US\$150 million in foreign investment has gone into Chinese dot.com companies. Most of these are internet content-providers and E-Commerce start-ups (The Economist, 22 July 2000).

\section{POTENTIAL AREAS OF DISPUTE}

As electronic commerce develops, it is inevitable that disputes will arise. Some disputes arising in cybertrade will obviously be similar to those disputes which already exist in the world of business. Trading on the internet will, however, bring in new areas of dispute previously unknown.

\section{Existing areas of dispute}

Electronic commerce transactions will give rise to the same kind of disputes which have traditionally arisen in commerce: complaints about defective goods. The majority of such claims arise in a domestic context. Closer to the operation of trading on the internet are crossborder transactions where exporters and importers carry on business in different countries.

In the past, transactions have involved much exchange and checking of paper documentation. More sophisticated transactions are likely to be encountered once electronic commerce begins to have an impact on international trade. The current view is that the old 'paper' trade procedures can no longer keep pace with the increased speed of commerce. Very often the international consignment of goods is held up because the paperwork cannot keep pace with the speed of development.

\section{New areas of dispute in cybertrade}

Cybertrade raises legal problems never faced before. Processes used in paper-based trading may not assist in the resolution of difficulties arising in cross-border trading on the world-wide web. A contract concluded online may involve problems not encountered in a written contract executed with the pen and ink signatures of the parties.

Trading on the internet is likely to create problems including the following:

- formation of a contract;

- signatures, encryption and authentication;

- electronic payment;
- intellectual property rights;

- governing law and jurisdiction;

- dispute resolution

\section{Formation of a contract}

A in Manchester is purchasing a book on the internet from B Limited in London. What form will this contract take? When and where will it be made? What will be its terms? If disputes develop, how can the existence of that contract be established in litigation or arbitration proceedings?

English case law has complex rules dealing with the formation of a contract. One basic rule is that there must be an offer and an acceptance. Does B Limited's Website contain an invitation to treat? Or is there an offer which can be accepted? And how is the acceptance of the offer to be communicated? Does A's click on an icon bring the contract into existence? And if it does, are there terms to be implied into that contract?

Say that A in London is purchasing his book from the B Corporation in America. Which law governs this contract? If it is the law of the seller's country, the United Nations Convention on Contracts for the International Sale of Goods (and the US Uniform Commercial Code) may have an impact. If no express provision is made in the contract, difficult questions may arise, not only as to the applicable law, but also as to the forum: do the English or American courts have jurisdiction?

Not only may the national laws require the contract to be in written form, but there may be the further requirement that the written document bear the written pen and ink - signatures of the parties. English law requires certain types of contract to be signed. How will ECommerce handle this? The answer being advanced is the Digital Signature: public key encryption can verify the identity of the sender.

Public and private key encryption technology can operate to keep electronic messages secure and can serve also as a method of authentication.

More important, is the company to which you are about to make payment under your electronic contract really the reputable B Corporation? Are you prepared to risk your credit card on the internet? Payment through some 'trusted third party' may be the answer.

\section{INTELLECTUAL PROPERTY RIGHTS}

Transactions on the internet are likely to involve online service providers transmitting and storing information from third parties. The service providers may - entirely innocently - infringe copyright.

The problems raised in relation to service providers and the infringement of copyright are part of a larger problem 
relating to intermediaries to whom information is supplied by third parties. If the information stored and transmitted is, unknown to the intermediary, of an illegal nature, what is the liability of the intermediary? Should this liability be limited?

\section{THE PARTICULAR PROBLEMS OF GOVERNING LAW AND JURISDICTION}

When the contract for the purchase and sale of a vehicle is made between A in London and the B Corporation in Germany, does the law of the country of the buyer or that of the country of the seller govern that contract and which country's courts have jurisdiction?

In the UK (and most of the European Union) the Rome Convention applies to identify the governing law. It will be the law of the country which is 'most closely connected' with the transaction. Likewise, the Brussels Convention deals with the question of which country's courts have jurisdiction over that contract. The EU Directive makes no provision in respect of governing law and jurisdiction, leaving the matter to the existing Conventions. But what is the position under a trans-border contract entered into between an EU and a non-EU party? Say the seller is in China and the buyer in Italy? Does the law of the seller's country apply? Do the courts of the seller's country have jurisdiction? Or in one or both cases is it the buyer's country?

The particular legal problems of governing law and jurisdiction have always existed in cross-border trading. Because electronic commerce is by its very nature a system of trading without national boundaries, problems relating to governing law and jurisdiction are likely to increase.

\section{NEW DISPUTE RESOLUTION PROCESSES FOR E-COMMERCE}

In China, CNNIC (the China internet Network Information Center) will seek to deal with the particular problem of cyber-squatting and domain names.

Two international organisations - the ICC in Paris and WIPO in Geneva - may also be showing the way ahead: WIPO, like CNNIC, is seeking to deal with domain name problems.

\section{CNNIC}

In China as in Britain, America and other countries worldwide, the problem of cyber-squatting is one which has caused considerable difficulties. In the first half of the year 2000, Beijing People's Court had more than 20 cases relating to domain name disputes. These related to cybersquatting by Chinese companies of domain names related to large multi-national foreign companies. In an effort to resolve these disputes, the CNNIC published the 'Solution to the disputes over domain names of China internet Network'. A non-government organisation will be chosen to handle these disputes. Additionally, on 15 August 2000, the
Beijing Higher People's Court issued 'several Guidelines on dealing with IP civil cases and disputes arising from the registration and usage of domain names'.

These Guidelines clarified the jurisdiction of the Chinese courts in relation to domain name disputes and will confirm that the applicable law shall continue to be the civil law of the PRC, specifically the PRC law on AntiUnfair Competition.

\section{DOCDEX}

The ICC may already have shown the way to resolve cross-border disputes swiftly and cost-effectively without the necessity for physical meetings. In October 1997 the ICC published the DOCDEX Rules, the 'Rules for Documentary Credit Dispute Resolution Expertise'. The system is made available through the ICC's International Centre for Expertise in Paris and can be used to resolve letter of credit disputes where the Credit is subject to the ICC's Uniform Customs and Practice for Documentary Credits (the UCP) or the Uniform Rules for Bank-toBank Reimbursement under Documentary Credits (URR).

The Rules provide for a swift, non-binding determination by a panel of three experts. There is no hearing. The party seeking a DOCDEX decision submits a 'request' which must identify the issues. The Request must be accompanied by the letter of credit in question and other relevant documents. The respondent submits an answer to which is annexed any relevant documents. Three 'appointed experts' are to draft a decision which is to be submitted to the Centre within 30 days. That decision is based on documents only. The Rules state that the parties may not seek an oral hearing in front of the appointed experts. After consulting with the ICC Banking Commission's technical adviser, the Centre issues the decision, which is deemed to be made in Paris on the date of its issue.

There is a standard fee for the DOCDEX service of US $\$ 5,000$. Where the amount of the letter of credit exceeds US $\$ 100,000$, an additional fee of up to 100 per cent of the standard fee may be charged.

In all probability the three Experts will be from three different countries. There is no requirement in the DOCDEX Rules that they should physically meet. The communications between the experts for the purposes of arriving at their decision can therefore be by telephone, fax or e-mail.

Parties involved in DOCDEX cases dealt with so far have come from more than 20 countries including Belgium, France, Italy, Spain, Switzerland, Turkey, Bulgaria, Hungary, China, India, USA and Australia.

The process is comparatively swift, and is likely to take between 100-120 days after the date of the receipt of the request to receive a DOCDEX decision. 
As stated earlier, the DOCDEX system is one which could be easily adapted so as to provide for online communication between the Panel of Experts, thus producing an electronic dispute resolution system ideally suited for the electronic commerce age.

\section{THE ICC AND ON-LINE ARBITRATION IN ELECTRONIC COMMERCE}

The ICC Commission on International Arbitration set up a working party to examine issues relating to arbitration and electronic commerce. It looked at whether online dispute resolution methods, such as online arbitration or alternatively the use of electronic techniques in traditional arbitration, are able to deal with disputes relating to electronic commerce.

Experiments have already been made: for example, WIPO is now offering expedited administrative proceedings for online internet domain name dispute resolution. Online arbitration would offer two advantages over traditional arbitration procedure: the parties would not have to travel to an arbitral tribunal hearing and proceedings (such as exchange of documents) would be almost instantaneous by electronic mail.

What law will apply to the arbitration proceedings, and to the merits of the dispute, where the arbitration is conducted in cyberspace? What is the 'seat' of an arbitration where it is conducted online? Is it the geographical location of the server through which the arbitration takes place?

Two specific problems may arise in relation to the proceedings themselves and the award. While it is probably possible under the ICC Arbitration Rules for a party to file a Request for Arbitration with the Secretariat in Paris electronically, there may potentially be difficulties in relation to the ICC requirement concerning the Terms of Reference. That requires a hand-written signature. Can this be dealt with electronically? Presumably this could be done by agreement of the parties. The requirement to exchange written submissions and documents under art. 20 and art. 22 of the ICC Rules should cause no difficulty.

There is no requirement under the Rules that the tribunal is obliged to hold hearings. Therefore, with the parties' consent, any necessary discussions could take place in the form of electronic exchanges. As to hearings, the technical means exist to hold these electronically through 'chat rooms'.

Various legal systems and international legal texts (for example the New York Convention and the UNCITRAL Model Law) contain requirements for writing and signature in relation to arbitral awards. The view is that new legislation may be required to give the same value to digitised signatures as to hand-written signatures.

One very obvious problem in relation to online arbitration would be the potential for fraudulent or accidental interference with documents. Cryptography or encryption may assist. Additionally, a system of acknowledgment of receipt of electronic mail exchanged during the arbitration proceedings could be organised through the arbitral institution itself 'which would thus have the role of an authenticating third party'.

Related to these problems are the difficulties of confidentiality in relation to an open network. This could be intercepted by other internet users, intentionally or otherwise:

'This problem, however, is neither new nor peculiar to online arbitration; it has appeared also in connection with payment operations and electronic commerce. Although real, the risks existing on the internet need to be put into perspective, as other traditional means of communication are not in fact always better protected despite seeming to be so: telephone communications and fax transmissions may also be intercepted by third parties'.

The working party recommended consideration be given to amending the fundamental texts of international arbitration to allow online arbitration to develop. It is likely that the use of online arbitration will really develop only when set up and supervised by experienced arbitral institutions whose structure enables them to follow through the procedure and conserve electronic records of its major stages. Such institutions have considerable authority, which should allow online arbitration to be more readily recognised as having the necessary legal security and reliability in the eyes of both users and state courts.

\section{WIPO}

The World Intellectual Property Organisation is one of a number of specialised agencies operated by the United Nations. For some time, WIPO has been working on an online dispute resolution system aimed at dealing with domain name disputes. Draft rules issued in 1997 contained provisions dealing with hearings. These were defined as including telephone or video conferencing and the 'simultaneous, authenticated exchange of electronic communications on the same channel in a manner that enables all parties authorised to use the channel to receive any communications sent and to send communications'.

Although intended specifically to deal with domain name disputes, the draft rules could be adapted to deal with online electronic commerce disputes generally. Erik Wilbers of the WIPO Arbitration and Mediation Center in Geneva has suggested that the expansion of electronic commerce on the internet 'may soon lead parties to settle disputes in the same manner as their commerce is conducted'.

He says that WIPO expects online mediation procedures for electronic commerce to increase access to dispute settlement mechanisms. He envisages enabling parties to initiate or defend claims by accessing a website and completing electronic forms which will guide them 
through the different stages of an electronic dispute resolution process. He states that WIPO hopes that Online Dispute Resolution will be able to increase the speed and efficiency with which dispute resolution processes are conducted: 'Web-based document filing systems will allow parties to submit instantaneously any number of documents over any distance, at virtually no cost. Submissions can be processed, stored and archived by automated document management systems, and their review from any location will be possible through a Webbased Interface on a 24-hour basis for parties with the required access rights. With the development of appropriate audio and video facilities, the parties also would have the possibility of conducting meetings or hearings on line, greatly reducing travel expenses and the costs of organising conference rooms.'

A legal framework is needed to form the basis of the Dispute Resolution Process. Erik Wilbers suggests that existing ADR Rules can provide the foundation:

'Issues that need to be addressed in particular are rights of access to the documents by the parties, applicable procedures in case of challenges of authenticity, contact details for notification purposes, calculation of time periods (in view of likely time-zone differences between the locations from which the parties are operating), and writing and signing the requirements for party communications and for the award'.

The proposed WIPO system is internet-based.

The WIPO domain name dispute resolution procedure is now operational. By mid-2000, more than 700 cases were being handled.

\section{SUMMARY}

Trading relationships have always given rise to disputes. Very often such disputes are settled between the traders themselves. Failing that, the national courts and arbitration - both national and international - have provided the means of resolving differences.

ADR has been developed in the US in the face of dissatisfaction with the costs and delays of both litigation and arbitration. Long before this, China had made considerable use of conciliation as a means of resolving disputes amicably, and continues to do so.

The growth of business on the internet, both businessto-business and business-to-consumer, will inevitably add not only to the number of disputes which arise but will increase the complexity of such disputes. Trading on the internet knows no borders and therefore to the existing areas of commercial disputes will be added new areas of potential differences relating to the formation of contracts, digital signatures, electronic payments, intellectual property rights and governing law and jurisdiction.

National courts and international arbitral bodies will have to deal with these disputes. In the $\mathrm{B} 2 \mathrm{~B}$ areas this

should not create too much difficulty. After all, transborder trading has taken place for centuries and businesses have used the national courts and - increasingly international commercial arbitration, to resolve their differences. In the $\mathrm{B} 2 \mathrm{C}$ area, however, the problems raised by cross-border commerce may come as a shock to consumers. In both the $\mathrm{B} 2 \mathrm{~B}$ and the $\mathrm{B} 2 \mathrm{C}$ areas, it is to be hoped that electronic commerce will give rise to electronic methods of dispute resolution.

Because electronic commerce knows no boundaries, there obviously may be limits to what individual national governments can do in relation to problems caused by ecommerce. The worldwide solution may have to come from an international body such as the United Nations.

In the meantime, the development of electronic commerce is likely to stay ahead of the politicians and lawyers who seek to grapple with the dispute resolution difficulties thrown up by commercial transactions carried out on the internet.

Anthony Connerty

Barrister, Lamb Chambers, Temple, London; consultant to the French law firm of Cabinet Sefrioui, Paris

Mr Connerty is a member of the panel of arbitrators of the China International Economic and Trade Arbitration Commission, Beijing (CIETAC); the World Intellectual Property Organisation, Geneva (WIPO); the Hong Kong International Arbitration Centre and Cairo Regional Centre for International Commercial Arbitration. He is a Fellow of the Chartered Institute of Arbitrators and of the Hong Kong Institute of Arbitrators. He is an Accredited Mediator with the Centre for Dispute Resolution, London.

This Paper is in part based upon the author's article 'Electronic Commerce: the UK View' which was published in a special edition of Sweet \& Maxwell's International Company and Commercial Law Review, and on a Lecture given at a Hawksmere Conference in London in May 2000. 